\title{
Questes
}

vestes Revue pluridisciplinaire d'études médiévales

$27 \mid 2014$

Naissances

\section{Naissances : éléments bibliographiques}

\section{Émilie Deschellette et Céline Ménager}

\section{(2) OpenEdition}

\section{Journals}

\section{Édition électronique}

URL : http://journals.openedition.org/questes/797

DOI : 10.4000/questes.797

ISSN : 2109-9472

\section{Éditeur}

Les Amis de Questes

\section{Édition imprimée}

Date de publication : 15 janvier 2014

Pagination : 159-174

ISSN : 2102-7188

\section{Référence électronique}

Émilie Deschellette et Céline Ménager, « Naissances : éléments bibliographiques », Questes [En ligne], 27 | 2014, mis en ligne le 15 janvier 2014, consulté le 15 septembre 2020. URL : http:// journals.openedition.org/questes/797 


\section{Éléments bibliographiques ${ }^{1}$}

\section{Le moment de la naissance}

Biller, Peter, «Childbirth in the Middle Ages », History Today, vol. 36, $n^{\circ} 8,1986$, p. 42-49.

DitTMar, Katherine K., Conceptions of children in early medieval society, thèse de doctorat, New Haven, Yale University, 1996.

Entrer dans la vie. Naissances et enfances dans la France traditionnelle, présenté par Jacques Gélis, Mireille Laget et Marie-France Morel, Paris, Gallimard/Julliard, coll. « Archives », 72, 1978.

Goodich, Michael E., From birth to old age. The human life cycle in medieval thought, 1250-1350, Lanham Md/London, University press of America, 1989.

HARRIS-STOERTZ, Fiona, «Pregnancy and childbirth in twelfth and thirteenth century French and English law », Journal of the History of Sexuality, vol. 21, n 2, 2012, p. 263-281.

Laurent, Sylvie, Naître au Moyen Âge. De la conception à la naissance. La grossesse et l'accouchement (XII $-X V^{e}$ siècle), Paris, Le Léopard d'or, 1989.

Lefebvre-Teillard, Anne, Autour de l'enfant. Du droit canonique et romain médiéval au Code civil de 1804, Leiden/Boston, Brill, coll. "Medieval Law and its practice», 2, 2008 ; en particulier le chapitre "Infans conceptus. Existence physique et existence juridique », p. 53-86.

MARKUS, Manfred, «Terms for pregnancy in the history of English : an onomasiological approach based on the OED», Neuphilologische Mitteilungen (Bulletin de la Société Néophilologique de Helsinki), vol. 106, n ${ }^{\circ} 1,2005$, p. 7-21.

1 Si l'on s'intéresse plus largement à l'enfance, l'on pourra consulter: DASEN, Véronique, LETT, Didier et Rollet, Catherine, « Dix ans de travaux sur l'enfance. Bibliographie récente sur l'histoire de l'enfance ", Annales de démographie historique, 2001, vol. 2, $\mathrm{n}^{\mathrm{o}} 102$, p. 47-100. 


\section{Naissances et parenté}

AleXAndre-Bidon, Danièle et LetT, Didier, Les Enfants au Moyen Âge, $V^{e}-X V^{e}$ siècles, Paris, Hachette, coll. « La Vie quotidienne »,1997.

CARRON, Robert, Enfant et parenté dans la France médiévale, $X^{\mathrm{e}}-$ XIII siècles, Genève, Droz, 1989.

Famille et parenté dans l'Occident médiéval, Actes du Colloque de l'École pratique des Hautes Études, en collaboration avec le Collège de France, à Paris les 6, 7 et 8 juin 1974, dir. George Duby et Jacques Le Goff, Rome, École française de Rome, 1977.

Fine, Agnès, Parrains, marraines. La parenté spirituelle en Europe, Paris, Fayard, 1994.

GreILSAMMER, Myriam, L'envers du tableau. Mariage et maternité en Flandre médiévale, Paris, Armand Colin, 1990.

Guerreau-Jalabert, Anita, "Parenté », dans le Dictionnaire raisonné de l'Occident médiéval, dir. Jacques Le Goff et Jean-Claude Schmitt, Paris, Fayard, 1999, p. 861-876.

—, "L'arbre de Jessé et l'ordre chrétien de la parenté », dans Marie. Le culte de la Vierge dans la société médiévale, dir. Dominique Iogna-Prat, Eric Palazzo, Daniel Russi, Georges Duby et Georges Rupalio, Paris, 1996, p. 137-170.

KLAPISCH-ZuBer, Christiane, L'ombre des ancêtres. Essai sur l'imaginaire médiéval de la parenté, Paris, Fayard, coll. «L'Esprit de la cité », 2000.

MarTin MCLaughlin, Mary, "Survivors and Surrogates. Children and Parents from the Ninth to the Thirteenth centuries ", The History of Childhood, éd. Lloyd de Mause, New York, Psychohistory Press, 1974, p. 101-181.

NeEL, Carol, Perspective on marriage, household, and children, Toronto/ Buffalo/London, University of Toronto Press/Medieval Academy of America, coll. « Medieval Academy reprints for teaching », 40, 2004.

Répudiation, séparation, divorce dans l'Occident médiéval, Actes du Colloque tenu à Valenciennes, 17-18 novembre 2005, dir. Emmanuèle Santinelli, Valenciennes, Presses Universitaires de Valenciennes, coll. « Recherches valenciennoises », 25, 2007. 


\section{Fondation dynastique et bâtardise}

AUTRAND, Françoise, «Naissance illégitime et service de l'État. Les enfants naturels dans le milieu de robe parisien, $\mathrm{XIV}^{\mathrm{e}}-\mathrm{XV}^{\mathrm{e}}$ siècle. », Revue historique, vol. 267, $\mathrm{n}^{\mathrm{O}} 2 / 254,1982$, p. 289-303.

«Bâtards et bâtardises dans les sociétés européennes. Normes, pratiques et représentations de la filiation illégitime. Moyen Âge, époque moderne (France, Espagne, Italie, Flandre, Allemagne) », Colloque international et pluridisciplinaire, organisé par Carole Avignon, Université d'Angers, UMR 6258-CERHIO, 10-12 octobre 2013.

«La Bâtardise et l'exercice du pouvoir », Colloque organisé à Liège par Alain Marchandisse, 16-17 octobre 2008.

Bastardy and its Comparative History. Studies in the history of illegitimacy and marital nonconformism in Britain, France, Germany, Sweden, North America, Jamaica and Japan, dir. Peter Laslett, Karla Oosterveen et Richard M. Smith, London, Arnold, 1980.

Boutet, Dominique, «Bâtardise et sexualité dans l'image littéraire de la royauté (XII $-\mathrm{XIII}^{\mathrm{e}}$ siècles) », dans Femmes. Mariages - Lignages, XII ${ }^{e}-$ $X I V^{e}$ siècles. Mélanges offerts à Georges Duby, éd. Jean Dufournet, Bruxelles, De Boeck/Wesnael, coll. «Bibliothèque du Moyen Âge », 1, 1992, p. 55-68.

BURR, Kenneth, «Bastardy at the court of Burgundy », Blanc Sanglier. A Magazine Produced by and for Yorkshire Members of the Richard III Society, vol. 15, nº 3, 1981, p. 3-7.

CARLIER, Myriam, "La politique des autorités envers les bâtards dans les Pays-Bas bourguignons : le dilemme entre avantage financier et intérêt politique ", dans Finances publiques et finances privées au bas Moyen $\hat{A} g e$, Actes du colloque tenu à Gand les 5 et 6 mai 1995, dir. Marc Boone, Walter Prevenier, Louvain, Appeldoorn/Garant, 1996, p. $203-$ 218.

DAVIES, T. R., « The glory of being a bastard ? », Coat of Arms, vol. n.s. 3, $\mathrm{n}^{\mathrm{o}} 108,1979$, p. 94-99.

«Famille et société à l'épreuve de la bâtardise. Normes, pratiques, représentations », 2 ème Journée d'étude du groupe « Filiation illégitime », organisée par Carole Avignon, Université d'Angers, UMR 6258CERHIO, 10 juin 2013. 
«Filiation illégitime et bâtardise dans les sociétés médiévale et moderne: des documents aux problématiques », Première journée d'étude du groupe « Filiation illégitime », organisée par Carole Avignon, Université d'Angers, UMR 6258-CERHIO, 21 janvier 2013.

GÉNESTAL, Robert, Histoire de la légitimation des enfants naturels en droit canonique, Paris, 1905.

Illegitimität im Spätmittelalter, München, Oldenbourg, coll. « Schriften des Historischen Kollegs », 29, 1994.

JAMME, Armand, "Bâtardise et patrimoine. Les débuts dans la vie d'Antoine de la Sale, 1386-1411 », Bibliothèque de l'École des Chartes, vol. 153, $\mathrm{n}^{\mathrm{o}} 1,1995$, p. 161-175.

Helmholz, Richard H., «Bastardy litigation in Medieval England», The American Journal of Legal History, 13, 1969.

HuET, Gédon, «La légende de Charlemagne bâtard et le témoignage de Jean Boendale », Le Moyen Âge, Bruxelles, De Boeck, 1911, $2^{\mathrm{e}}$ série, t. XXV, p. 162-173.

HARSGOR, Michaël, «L'essor des bâtards nobles au Xv ${ }^{\mathrm{e}}$ siècle », Revue Historique, 253, 1975, p. 319-354.

KuEHN, Thomas, «Family, inheritance, and illegitimacy. A case from early Quattrocento Florence », Viator. Medieval and Renaissance Studies, vol. 37, 2006, p. 417-432.

LEFEBVRE-TeILLARD, Anne, «L'enfant naturel dans l'ancien droit français », Recueil de la société Jean Bodin, 36/2, 1976, p. 253-264.

L'Hermite-LeclercQ, Paulette, «Solus Deus heredem facit. Une histoire d'accouchement simulé en Angleterre à la fin du XII ${ }^{\mathrm{e}}$ siècle », dans Femmes. Mariages - Lignages, XII ${ }^{e}-X I V^{e}$ siècles. Mélanges offerts à Georges Duby, éd. Jean Dufournet, Bruxelles, De Boeck/Wesnael, coll. «Bibliothèque du Moyen Âge », 1, 1992, p. 257-272.

"Naissance et petite enfance à la cour de France (Moyen Âge-XIX ${ }^{\mathrm{e}}$ siècle) », journées d'étude internationales organisées par Stanis Pérez et Caroline Zum Kolk les 27 et 28 février 2014 à la Maison des Sciences de l'Homme Paris Nord, dans le cadre du projet scientifique «Cour de France.fr » et avec la collaboration du programme inter-universitaire «Formes du savoir de 1400 à 1750» (Maison des Sciences de l'Homme Aquitaine). 
PARSONS, John Carmi, « Damned if she didn't and damned if she did. Bodies, babies, and bastards in the lives of two queens of France », dans Eleanor of Aquitaine. Lord and Lady, éd. Bonnie Wheeler et John Carmi Parsons, New York, Palgrave Macmillan, coll. «The New Middle Ages », 2002, p. 265-299.

Regnault, Henri, La condition juridique du bâtard au Moyen Âge, Pont-Audemer, Impr. Lescuyer, 1922.

SAVy, Pierre, «Un début dans la vie. Sforza Secondo jusqu'en 1467 », Médiévales. Langue, textes, histoire (Paris), vol. 48, 2005, p. 15-37.

SCHIMMELPFENNIG, Bernhard, "Ex fornicatione nati". Studies on the position of priests' sons from the twelfth to the fourteenth century ", Studies in Medieval and Renaissance History, vol. n.s. 2, 1979, p. 1-50.

SlanicKA, Simona, " "Tamquam legitimus". Bastarde in spätmittelalterlichen Legitimationsbriefen ", dans Recht und Verhalten in vormodernen Gesellschaften. Festschrift für Neithard Bulst, éd. Andrea Bendlage, Andreas Priever et Peter Schuster, Bielefeld, Verlag für Regionalgeschichte, 2008, p. 103-122.

SOMMÉ, Monique, «Le cérémonial de la naissance et de la mort de l'enfant princier à la cour de Bourgogne au $\mathrm{XV}^{\mathrm{e}}$ siècle », Publications du Centre européen d'études bourguignonnes (XIV ${ }^{e}-X V I^{e}$ s.), 1994, vol. 34, p. 87103.

SuJIMON, Mohamad Som, "Preservation of progeny in Islamic law with regard to foundlings and illegitimate children », Islamic Quarterly, vol. 53, n 4, 2009, p. 309-342.

Staniland, Kay, "Royal entry into the world», dans England in the Fifteenth Century. Proceedings of the 1986 Harlaxton Symposium, éd. Daniel Williams, Woodbridge, Boydell \& Brewer, 1987, p. 297-313.

WERTHEIMER, Laura, "Illegitimate birth and the English clergy, 1198$1348 »$, Journal of Medieval History, vol. 31, n 2, 2005, p. 211-229.

- " Continuity and change in constructs of illegitimacy between the second and eighth centuries », Historical Reflections, vol. 33, $\mathrm{n}^{\mathrm{O}} 3,2007$, p. 363-393.

\section{Naissance et questions de genre(s)}

BÜHrer-THIERry, Geneviève, LETT, Didier et MOULINIER-Brogi, Laurence, "Histoire des femmes et histoire du genre dans l'Occident médiéval », Historiens-Géographes, ${ }^{\circ}{ }^{\circ} 392,2005$, p. 135-146. 
CAdDen, Joan, Meanings of Sex Difference in the Middle Ages. Medecine, Science and Culture, Cambridge, Cambridge University Press, 1993.

Femmes. Mariages-Lignages, XII ${ }^{e}-X I V^{e}$ siècles, Mélanges offerts à Georges Duby, dir. Jean Dufournet, André Joris et Pierre Toubert, Bruxelles, De Boeck Université, 1992.

LETT, Didier, Famille et parenté dans l'Occident médiéval. $V^{e}-X V^{e}$ siècle, Paris, Hachette, coll. « Carré Histoire », 2000.

-, Hommes et femmes au Moyen Âge. Histoire du genre. XII ${ }^{e}-X V^{e}$ siècle, Paris, Armand Colin, coll. « Cursus Histoire », 2013.

HÉRITIER, Françoise, L'Exercice de la parenté, Paris, Gallimard/Éditions du Seuil, coll. « Hautes études », 1981, p. 14-15.

-, Masculin/Féminin. La pensée de la différence, Paris, Éditions Odile Jacob, 1996

ZAPPERI, Roberto, L'uomo incinto. La donna, l'uomo e il potere, Lerici, Cosenza, 1979; trad. fran. Marie-Ange Maire-Vigueur, L'Homme enceint. L'homme, la femme et le pouvoir, Paris, PUF, coll. «Les Chemins de l'histoire », 1983.

\section{Le sentiment de maternité}

AtKInson, Clarissa W., The oldest vocation. Christian motherhood in the Middle Ages, Ithaca/Londres, Cornell University Press, 1991.

Desclais-BerkVAm, Doris, Enfance et maternité dans la littérature française des XII et XIII siècles, Paris, Champion, coll. « Essais », 1981.

Medieval mothering, éd. John Carmi Parsons et Bonnie Wheeler, New York/London, Garland Publishing, coll. « The new Middle Ages », 3, 1996.

La Mère au Moyen Âge, Actes du colloque du Centre d'études médiévales et dialectales de l'Université Charles-de-Gaulle - Lille 3, 25, 26 et 27 septembre 1997, éd. Aimé Petit, Villeneuve d'Ascq, Centre d'étude médiévale et dialectale de Lille 3, coll. «Bien dire et bien aprandre », 16, 1998.

TAVORMINA, Teresa M., "Of maidenhood and maternity: liturgical hagiography and the medieval idea of virginity », American Benedictine Review, vol. 31, n 4, 1980, p. 384-399. 
Worth-Stylianou, Valérie, «Les caquets de l'accouchée. La représentation de la maternité dans la littérature fictive (ca. 14751622) », dans Female Saints and Sinners. Saintes et mondaines (France 1450-1650), éd. Jennifer Britnell et Ann Moss, Durham, University of Durham, 2002, p. 251-265.

\section{La représentation de la paternité}

BASCHET, Jérôme, Le sein du père. Abraham et la paternité dans l'Occident médiéval, Paris, Gallimard, coll. «Le Temps des images », 2000.

Etre père à la fin du Moyen Age, dir. Didier Lett, Cahiers de Recherches Médiévales (XIIII ${ }^{e}-X V^{e}$ siècle), 1997, $\mathrm{n}^{\circ} 4$.

HAAS, Louis, The Renaissance man and his children. Chilbirth and early childhood in Florence, 1300-1600, Basingstoke, Macmillan, 1998.

LEE, Becky R., «A company of women and men : men's recollections of childbirth in medieval England », Journal of Family History. Studies in Family, Kinship and Demography, vol. 27, n 2 2, 2002, p. 92-100.

LETT, Didier, «Tendres souverains. Historiographie et histoire des pères au Moyen Age », dans Histoire des pères et de la paternité [1990], éd. Jean Delumeau et Daniel Roche, Paris, Larousse, 2000.

Payan, Paul, Joseph. Une image de la paternité dans l'Occident médiéval, Paris, Aubier, coll. « Collection historique », 2006.

\section{Procréation, naissance et Église}

BASCHET, Jérôme, « Ève n'est jamais née. Les représentations médiévales et l'origine du genre humain», Ève et Pandora. La création de la première femme, dir. Jean-Claude Schmitt, Paris, Gallimard, 2002, p. $115-162$.

—, «La parenté partagée : engendrement charnel et infusion de l'âme (à propos d'une miniature de la fin du $\mathrm{XV}^{\mathrm{e}}$ siècle) », dans Anima et corpo nella cultura medievale. Atti del V Convegno di studi della Società Italiana per lo Studio del Pensiero Medievale, Venezia, 25-28 settembre 1995, éd. Carla Casagrande et Sivana Vecchio, Firenze, SISMEL-Ediziono del Galluzo, 1999, p. 123-138.

Bloch, Maurice et GuggenheIm, Stephen, «Compadrazgo, Baptism and the Symbolism of a second Birth », Man, New Series, vol. 16, $\mathrm{n}^{\circ}$ 13, sept. 1981, p. 376-386. 
Guerreau-Jalabert, Anita, «Spiritus et caritas. Le baptême dans la société médiévale », dans La Parenté spirituelle, éd. Françoise HéritierAugé Elisabeth Copet-Rougier, Paris, Édition des Archives contemporaines, 1996, p. 133-203.

EGILSDÓTIR, Ásdís, «St Margaret, patroness of childbirth», dans Mythological Women. Studies in Memory of Lotte Motz 1922-1997, éd. Rudolf Simek et Wilhelm Heizmann, Wien, Fassbaender, coll. « Studia Medievalia Septentrionalia », 7, 2002, p. 319-330.

ELSAKKERS, Marianne, «In pain you shall bear children (Gen. 3, 16). Medieval prayers for a safe delivery », dans Women and Miracle Stories. A Multidisciplinary Exploration, éd. Anne-Marie Korte, Leiden, Brill, coll. « Studies in the History of Religions », 88, 2001, p. 179-207.

FLANDRIN, Jean-Louis, L'Église et le contrôle des naissances, Paris, Flammarion, coll. «Questions d'histoire », $\mathrm{n}^{\mathrm{o}} 23,1970$.

FRÖJMARK, Anders, « Childbirth miracles in Swedish miracle collections », Journal of the History of Sexuality, vol. 21, n ${ }^{\circ}$ 2, 2012, p. 297-312.

LEE, Becky R., « The purification of women after childbirth. A window onto medieval perceptions of women », Florilegium. Carleton University Annual Papers on Classical Antiquity and the Middle Ages, vol. 14, 1996, p. 43-55.

-, «Men's recollection of a woman's rite. Medieval English men's recollections regarding the rite of the purification of women after childbirth », Gender and History, vol. 14, n 2, 2002, p. 224-241.

Metz, René. La femme et l'enfant dans le droit canonique médiéval, London, Variorum Reprints, coll. « Collected studies series », 222, 1985.

Noonan, John T., Contraception. A History of treatment by the Catholic Theologians and Canonists [1965], trad. fran. par Marcelle JossuA, Contraception et mariage. Évolution ou contradiction dans la pensée chrétienne, Paris, Éditions du Cerf, 1969.

PIERCE, Joanne M., «"Green women” and blood pollution. Some medieval rituals for the churching of women after childbirth », Studia liturgica, vol. 29, no 2, 1999, p. 191-215.

QuirogA, Laura Cecilia, « De la concepción al nacimiento. La maternidad en las Cantigas de Santa María », Temas medievales, vol. 13, 2005, p. $173-184$.

RAWCLIFFE, Carole, «Women, childbirth, and religion in later medieval England », dans Women and Religion in Medieval England, éd. Diana Wood, Oxford, Oxbow Books, 2003, p. 91-117. 
Richards, Mary P., «A Middle English prayer to ease chilbirth », Notes and Queries, vol. n.s. 27, $\mathrm{n}^{\mathrm{o}}$ 4, 1980, p. 292.

Thomas D’AquIN, Summa Theologiae, Summa theologiae cum Supplemento et commentariis Caietani, Rome Textum Leoninum Romae, 1886-1906, mis en ligne par le Corpus Thomisticum de la Fundación Tomás de Aquino: http:/www.corpusthomisticum.org/ index.html (en particulier Prima Pars, quaestiones 27, 33, 41). Somme théologique, trad. fran. Aimon-Marie Roguet, coord. Albert Raulin, Paris, Éditions du Cerf, 4 vol., 1984-1986, vol. 1.

Saint Augustin, De bono conjugali, dans Euvres de saint Augustin, 2, «Problèmes moraux», texte de l'édition bénédictine; traduction, introduction et notes par Gustave Combès, 1948.

\section{Connaissances médicales et pratiques intimes}

ChARDONNENS, László Sándor, «A new edition of the Old English Formation of the Foetus », Notes and Queries, vol. n.s. 47, n ${ }^{0}$ 1, 2000, p. $10-11$.

FIORAVANTI, Gianfranco, «Un trattato medievale di eugenetica. Il Libellus de ingenio bone navitatis », Medicevalia - Textos e Estudos, vol. 21, 2002, p. 89-111.

—, « Eugenetica alla corte di Giacomo II d'Aragona. Il Libellus de ingenio bone nativitatis », Micrologus: Natura, scienze e società medievali. Nature, Sciences and Medieval Societies, vol. 16, 2008, p. 393-403.

GrEeN, Monica H., «Obstetrical and gynecological texts in Middle English », dans Monica Green, Women's Healthcare in the Medieval West: Texts and Contexts, Aldershot, Ashgate, coll. «Variorum Collected Studies », CS860, 2000, p. IV : 53-88.

JACQUART, Danielle et THOMASSET, Claude, Sexualité et savoir médical au Moyen Âge, Paris, Presses universitaires de France, coll. « Les Chemins de l'histoire $», 1985$.

KRUSE, Britta-Juliane, « Women's secrets. Health and sexuality of women in unpublished medieval texts ", dans Sex, Love and Marriage in Medieval Literature and Reality. Thematische Beiträge im Rahmen des 31th International Congress on Medieval Studies an der Western Michigan University (Kalamazoo-USA), 8-12 Mai 1996, éd. Danielle Buschinger et Wolfgang Spiewok, Greifswald, Reineke Verlag, coll. « Greifswalder Beiträge zum Mittelalter », 56, 1996, p. 33-46.

PALMER, Nigel F., «Die lateinisch-deutsche Berliner Nativitätsprognostik», dans Licht der Natur. Medizin in Fachliteratur und 
Dichtung. Festschrift für Gudolf Keil zum 60. Geburtstag, éd. Josef Domes, Göppingen, Kümmerle, coll. «Göppinger Arbeiten zur Germanistik », 585, 1994, p. 251-291.

\section{Pratiques de l'accouchement}

GARVER, Valerie L., "Childbearing and infancy in the Carolingian world », Journal of the History of Sexuality, vol. 21, 2012, n 2, p. 208244.

GiBSON, Gail McMurray, « Scene and obscene. Seeing and performing late medieval childbirth », Journal of Medieval and Early Modern Studies (formerly Journal of Medieval and Renaissance Studies), vol. 29, 1999, $\mathrm{n}^{\mathrm{o}} 1, \mathrm{p} .7-24$.

GreEN, Monica H., «Women's medical practice and health care in medieval Europe », dans Monica Green, Women's Healthcare in the Medieval West. Texts and Contexts, Aldershot, Ashgate, coll. « Variorum Collected Studies », CS860, 2000, p. I : 39-78.

HAAS, Louis, "Women and childbearing in medieval Florence », dans Medieval Family Roles. A Book of Essays, éd. Cathy Jorgensen Itnyre, New York, Garland, coll. « Garland Medieval Casebooks », 15, 1996, p. 87-99.

KERHERVÉ, Jean, «Un accouchement dramatique à la fin du Moyen Age », Annales de Bretagne et des pays de l'Ouest, vol. 89, $\mathrm{n}^{\mathrm{O}} 3$ 3, 1982, p. 391396.

KUENY, Kathryn, « The cure of perfection. Women's obstetrics in early and medieval Islam », dans Perspectives on Medieval Art. Learning through Looking, éd. Ena Giurescu Heller et Patricia C. Pongracz, London, D. Giles Limited, 2010, p. 187-197.

MAFART, Bertrand-Yves, «Approche de la mortalité maternelle au Moyen Age en Provence », dans La Femme pendant le Moyen Âge et l'Époque moderne. Actes des Sixièmes Journées Anthropologiques de Valbonne, 9-11 juin 1992, éd. Luc Buchet, Paris, CNRS Éditions, coll. «Dossiers de Documentation Archéologique », 17, 1994, p. 207-219.

OBerRauch, Barbara, "Die Frau und ihr Körper. Frauenmedizinische Aspekte des mittelalterlichen Alltagslebens », Innsbrucker historische Studien, 2004, vol. 23-24, p. 43-126.

SALVAT, Michel, «L'accouchement dans la littérature scientifique médiévale », Senefiance, vol. 9, L'Enfant au Moyen Âge, 1980, p. 87106. 
StOertz, Fiona Harris, «Suffering and survival in medieval English childbirth », dans Medieval Family Roles. A Book of Essays, éd. Cathy Jorgensen Itnyre, New York, Garland, coll. « Garland Medieval Casebooks », 15, 1996, p. 101-120.

Weston, Lisa M. C. «Women's medicine, women's magic. The Old English metrical childbirth charms », Modern Philology. A Journal Devoted to Research in Medieval and Modern Literature, vol. 92, 1995, $\mathrm{n}^{\mathrm{o}} 3$, p. 279-293.

WitKOWSKI, Gustave-Joseph, Histoire des accouchements chez tous les peuples, Paris, G. Steinheil, 1889, 2 vol.

\section{Contraception et avortement}

Bologne, Jean-Claude, La Naissance interdite. Stérilité, avortement, contraception au Moyen Âge, Paris, O. Orban, 1988.

CALlan, Maeve B., «Of vanishing fetuses and maidens made-again: abortion, restored virginity, and similar scenarios in medieval Irish hagiography and penitentials », Journal of the History of Sexuality, 2012, vol. $21, n^{\circ} 2$, p. 282-296.

ELSAKKERS, Marianne, «Abortion, poisoning, magic, and contraception in Eckhardt's Pactus Legis Salicae », Amsterdamer Beiträge zur älteren Germanistik, vol. 57, 2003, p. 233-267.

LEE, Patrick et HALDANE, John J., «Aquinas on human ensoulment, abortion and the value of life », Philosophy. The Journal of the Royal Institute of Philosophy, vol. 78, $\mathrm{n}^{\mathrm{o}}$ 304, 2003, p. 255-278.

RIDDLE, John M., « Contraception and early abortion in the Middle Ages », dans Handbook of Medieval Sexuality, éd. Vern L. Bullough et James A. Brundage, New York, Garland, coll. « Garland Reference Library of the Humanities », 1696, 1996, p. 261-277.

WiCKER, Nancy L., «Christianization, female infanticide, and the abundance of female burials at Viking Age Birka in Sweden », Journal of the History of Sexuality, vol. 21, n ${ }^{\circ} 2,2012$, p. 245-262. 


\section{La sage-femme, la nourrice et le lait}

Fildes, Valérie, Wet Nursing. A History from Antiquity to the Present. Oxford/New York, Blackwell, coll. « Family, Sexuality a. Soc. Relat. in Past Times », 1988.

Forbes, Thomas R., The Midwife and the Witch, New Haven, Yale University Press, 1966.

GILADI, Avner, "Liminal craft, exceptional law. Preliminary notes on midwives in medieval Islamic writings », International Journal of Middle East Studies, vol. 42, n 2 2, 2010, p. 185-202.

GreEn, Monica H. et SMAIL Daniel Lord, "The trial of Floreta d'Ays (1403). Jews, Christians, and obstetrics in later medieval Marseille », Journal of Medieval History, vol. 34, n 2, 2008, p. 185-211.

GreILSAMmer, Myriam, "The midwife, the priest, and the physician. The subjugation of midwives in the Low Countries at the end of the Middle Ages ", Journal of Medieval and Renaissance Studies (later Journal of Medieval and Early Modern Studies), vol. 21, n 2, 1991, p. 285-329.

JuHEL, Vincent, «Le bain de l'Enfant-Jésus. Des origines à la fin du douzième siècle », Cahiers archéologiques. Fin de l'Antiquité et Moyen Âge, vol. 39, 1991, p. 111-132.

KLAPISCH-Zuber, Christiane, «Parents de sang, parents de lait. La mise en nourrice à Florence (1300-1530) », Annales de démographie historique, 1983, p. 33-64.

«Lactation in History : a Crosscultural Research on Suckling Practices, Representations of Breastfeeding and Politics of Maternity in a European Context », projet de recherche des Universités de Genève, Fribourg et Lausanne, soutenues par le FNS, dir. Yasmina Foehr-Janssens, Daniela Solfaroli Camillocci, Véronique Dasen et Irene Maffi.

MolenAT, Jean-Pierre, «Privilégiées ou poursuivies. Quatre sages-femmes musulmanes dans la Castille $\mathrm{du} \mathrm{XV}^{\mathrm{e}}$ siècle », dans Identidades marginales, éd. Cristina de la Puente, Madrid, Consejo Superior de Investigaciones Científicas, coll. « Estudios onomástico-biográficos de al-Andalus », 13, 2003, p. 413-430.

Neuman de Vegvar, Carol Leslie, "Images of women in Anglo-Saxon art, II : midwifery in Harley $603 »$, Old English Newsletter, vol. 25, $\mathrm{n}^{\circ} 1$, 1991, p. 54-56. 
PADEN William D. et PADEN Frances Freeman, «Swollen woman, shifting canon. A midwife's charm and the birth of secular Romance lyric », PMLA. Publications of the Modern Language Association of America, vol. $125, \mathrm{n}^{\mathrm{o}} 2,2010$, p. 306-321.

RYAN, Denise, « Playing the midwife's part in the English Nativity plays », Review of English Studies. The Leading Journal of English Literature and the English Language, vol. n.s. 54, n ${ }^{\circ} 216,2003$, p. 435-448.

SAUNIER, A. «Le visiteur, les femmes et les "obstetrices" des paroisses de l'archidiaconé de Josas de 1458 à $1470 »$, dans Santé, médecine et assistance au Moyen Age. Tome 1, Section d'histoire médiévale et de philologie, actes du $110^{e}$ congrès national des sociétés savantes, Montpellier, 1985, Paris, Éditions du CTHS, 1987.

SurTz, Ronald, «A Spanish midwife's uses of the word. The inquisitorial trial $(1485 / 86)$ of Joana Torrellas », Mediaevistik. Internationale Zeitschrift für interdisziplinäre Mittelalterforschung, vol. 19, 2006, p. 153-168.

WIESNER, Merry E., "Early modern midwifery. A case study », dans Women and Work in Preindustrial Europe, éd. Barbara A. Hanawalt, Bloomington, Indiana, Indiana University Press, 1986, p. 94-113.

WINER, Rebecca Lynn, «Conscripting the breast. Lactation, slavery and salvation in the realms of Aragon and kingdom of Majorca, ca. 12501300 », Journal of Medieval History, vol. 34, n 2, 2008, p. 164-184.

\section{Naissances singulières, naissances monstrueuses}

ARCHIBALD, Elizabeth, Incest and the Medieval Imagination, Oxford, Clarendon Press, 2001.

BELmont, Nicole, Les signes de la naissance. Études des représentations symboliques associées aux naissances singulières, Paris, Librairie Plon, 1971.

BlumenFELD-Kosinski, Renate, "Gautier de Coinci and medieval childbirth miracles », dans Gautier de Coinci. Miracles, Music, and Manuscripts, éd. Kathy M. Krause, Alison Stones, Turnhout, Brepols, coll. «Medieval Texts and Cultures of Northern Europe », 13, 2006, p. 197-214.

DASEN, Véronique, «Blessing or Portent? Multiple births in ancient Rome », dans Hoping for Continuity. Childhood, Education and Death in Antiquity and the Middle Ages, éd. Katarina Mustakallio, Jussi Hanska, Hanna-Leena Sainio et Ville Vuolanto, Roma, Institutum 
Romanum Finlandiae, coll. «Acta Instituti Romani Finlandiae », 33, 2005, p. 61-73.

Le Monstre et sa lignée. Filiations et générations monstrueuses dans la littérature latine et sa postérité, dir. Jean-Pierre De Giorgio et Fabrice Galtier, Paris, L’Harmattan, coll. « Kubaba », 2012.

Pline L'AnCIEN, Histoire naturelle, Livre VII, texte établi, traduit et commenté par Robert Schilling, $2^{\text {ème }}$ tirage revu et corrigé, Paris, Les Belles Lettres, 2003, en particulier les chapitres: «Enfantements prodigieux », « De la génération de 1'homme ; Exemples célèbres de gestations » et « Enfantements monstrueux ».

Saint Augustin, De Civitate Dei, Livre XVI, chapitre VIII, La Cité de Dieu. Livres $X V$-XVIII, Saint Augustin; texte de la $4^{\text {ème }}$ édition de Bernhard Dombart et Alfons Kalb, introduction générale et notes par Gustave Bardy; traduction française de Gustave Combès, Paris, Desclée-Brouwer, coll. « Bibliothèque Augustinienne », 1980.

VAN Der Lugt, Maaike, Le ver, le démon et la Vierge. Les théories médiévales de la génération extraordinaire: une étude sur les rapports entre théologie, philosophie naturelle et médecine, Paris, Les Belles Lettres, coll. « L'âne d'or », 2004.

\section{Naissances et fiction}

AguiRiand, Begoña, « Les images de la mort-naissance initiatique dans les romans de Chrétien de Troyes », dans Éducation, apprentissages, initiation au Moyen Age. Actes du premier colloque international de Montpellier, Université Paul Valéry, novembre 1991, Montpellier, Centre de Recherche Interdisciplinaire sur la Société et 1'Imaginaire au Moyen Age, coll. «Les Cahiers du C.R.I.S.I.M.A.», 1, 1993, vol. I, p. 9-22.

ÉCHÈne, Agnès, " Mélusine, ancêtre de lignée », dans Les Mères de la patrie, Caen, Cahiers de la MRSH, 2007.

Enfances arthuriennes, Actes du $2^{\mathrm{e}}$ colloque arthurien de Rennes, 6 et 7 mars 2003, dir. Christine Ferlampin-Acher et Denis Hüe, Orléans, Paradigme, 2006.

GiBert, Pierre, L'inconnue du commencement, Paris, Éditions du Seuil, coll. « La couleur des idées », 2007.

Lignes et lignage dans la littérature arthurienne, Actes du $3^{\mathrm{e}}$ colloque arthurien de Rennes, 13 et 14 octobre 2005, dir. Christine 
Ferlampin-Acher et Denis Hüe, Rennes, Presses Universitaires de Rennes, coll. «Interférences», 2007.

L'Imaginaire de la parenté dans les romans arthuriens (XII $-X I V^{e}$ siècles). Actes du colloque international du Centre d'Études Supérieures de Civilisation Médiévale de l'Université de Poitiers (12 et 13 juin 2009), éd. Martin Aurell et Catalina Girbea, Turnhout, Brepols, coll. « Histoires de famille. La parenté au Moyen Âge », 11, 2010.

Mathey-Maille, Laurence, « Le roi Arthur chez Geoffroy de Monmouth et Wace: la naissance du héros ", Arturus Rex. Acta Conventus Lovaniensis 1987, éd. Willy van Hoecke, Gibert Tournoy, Werner Verbeke, Leuven, Leuven University Press, Series I/Studia XVII, 1991, p. $222-229$

MÉLA, Charles, «Le motif des enfances, le mystère de l'origine et le roman en prose ", Perspectives médiévales. Bulletin périodique publié par la Société de Langue et de Littérature Médiévales d'Oc et d'Oï, Octobre $\mathrm{n}^{\mathrm{o}} 3,1977$, p. 65-70.

PARADIS, Françoise, « La triple mise au monde d'un héros, ou trois images d'une féminité maîtrisée dans le début du Lancelot en prose ", dans Approches du Lancelot en prose, dir. Jean Dufournet, Paris, Champion, 1984, p. 157-176.

RANK, Otto, Le mythe de la naissance du héros, Paris, Payot, 1983 [ 1 ère édition allemande: Der Mythus von der Geburt des Helden, Leipzig/Wien, F. Deuticke, 1909].

ROBERT, Marthe, Roman des origines et origines du roman, Paris, Grasset, 1972.

VALETTE, Jean-René, « Filiation charnelle et adoption filiale : l'imaginaire de la paternité dans la Queste del Saint Graal», dans L'Imaginaire de la parenté dans les romans arthuriens (XII $-X I \nu^{e}$ siècles). Actes du colloque international du Centre d'Études Supérieures de Civilisation Médiévale de l'Université de Poitiers (12 et 13 juin 2009), éd. Martin Aurell et Catalina Girbea, Turnhout, Brepols, coll. « Histoires de famille. La parenté au Moyen Âge », 11, 2010, p. 47-59. 


\section{Naissance de l'œuvre}

Bloch, R. Howard, «Genealogy as a Medieval Mental Structure and Textual Form », dans La Littératutre historiographique des origines à 1500, Grundriss der romanischen Literaturen des Mittelalters, Heidelberg, Carl Winter Universistätsverlag, 1986, p. 135-156.

-, Etymologies and Genealogies. A literay Anthropology of the French Middle Ages, Chicago/London, 1983 ; trad. fran. par Béatrice Bonne et Jean-Claude Bonne, Etymologie et généalogie. Une anthropologie du Moyen Âge français, Paris, Éditions du Seuil, 1989.

Cerquiglini-Toulet, Jacqueline, «L'inspiration des poètes lyriques à la fin du Moyen Âge : le cas de Christine de Pizan ", dans L'inspiration. Le souffle créateur dans les arts, littératures et mystiques du Moyen Âge européen et proche-oriental. Colloque international tenu en Sorbonne les 23-24 mai 2002, éd. Claire Kappler et Roger Grozelier, Paris/Budapest/Kinshasa, L'Harmattan, coll. « Kubaba Actes », 8, 2006, p. 291-302.

Mulligan, Amy C., "“The satire of the poet is a pregnancy". Pregnant poets, body metaphors, and cultural production in medieval Ireland », Journal of English and Germanic Philology, vol. 108, n ${ }^{\circ} 4,2009$, p. 481-505.

Seuils de l'œuvre dans le texte médiéval, dir. Emmanuèle Baumgartner et Laurence Harf-Lancner, Paris, Presse de la Sorbonne Nouvelle, 2002, 2 vol.

TAYlor, Jane H., « The Sense of a Beginning. Genealogy and Plenitude in Late Medieval Narrative Cycles ", Transtextualities. Of cycles and cyclicity in medieval French literature, éd. Donald Maddox et Sara Sturm-Maddox, New York, Center for Medieval et Early Renaissance Studies, 1996. 